Objects of Desire 
Also by Beryl Schlossman

Toyce's Catholic Comedy of Language

The Orient of Style: Modernist Allegories of Conversion

Angelus Novus 


\title{
Objects of Desire
}

\author{
The Madonnas \\ of Modernism
}

\section{BERYL SCHLOSSMAN}

CORNELL UNIVERSITY PRESS

ITHACA AND LONDON 


\section{Copyright $\mathbb{C}$ I 999 by Cornell University}

All rights reserved. Except for brief quotations in a review, this book, or parts thereof, must not be reproduced in any form without permission in writing from the publisher. For information, address Cornell University Press, Sage House, 5 I 2 East State Street, Ithaca, New York I 4850.

First published I 999 by Cornell University Press

Printed in the United States of America

\section{Library of Congress Cataloging-in-Publication Data}

Schlossman, Beryl

Objects of desire : the madonnas of modernism / Beryl Schlossman.

p. $\mathrm{cm}$.

Includes bibliographical references and index.

ISBN 0-80 I 4-3649-4 (cloth : alk. paper)

I. Modernism (Literature) 2. Literature, Modern-2oth century-History and criticism. 3. Literature, Modern - i gth century-History and criticism.

4. Literature, Modern-Classical influences. 5. Virginity in literature.

6. Desire in literature. 7. Women in literature. 8. Love in literature. I. Title. PN56.M54536 I999

$809^{\prime} .9$ I I $2-\mathrm{dc}_{2}$ I

$99-32826$

Cornell University Press strives to use environmentally responsible suppliers and materials to the fullest extent possible in the publishing of its books. Such materials include vegetable-based, low-VOC inks, and acid-free papers that are recycled, totally chlorine-free, or partly composed of nonwood fibers. Books that bear the logo of the FSC (Forest Stewardship Council) use paper taken from forests that have been inspected and certified as meeting the highest standards for environmental and social responsibility. For further information, visit our website at www.cornellpress.cornell.edu.

Cloth printing $\quad 1098765432 \mathrm{I}$
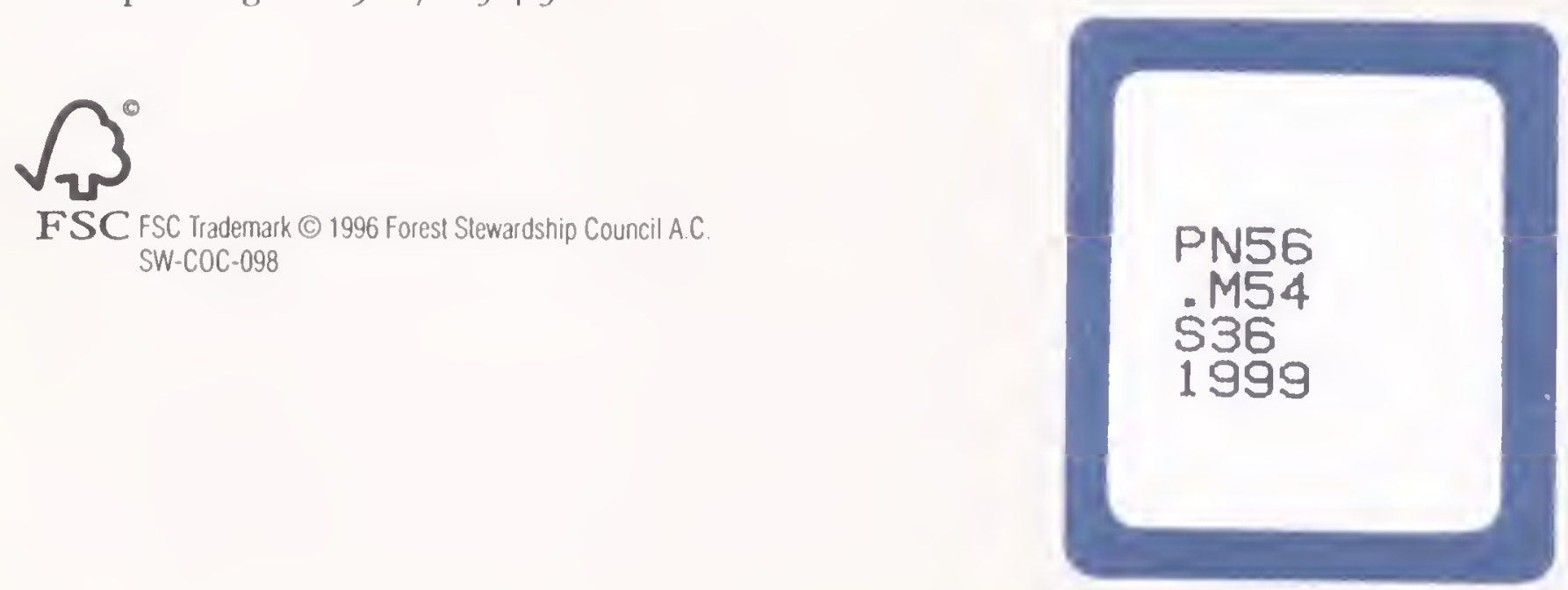